\title{
Implementasi pemanfaatan google classroom, google meet, dan instagram dalam proses pembelajaran online menuju abad 21
}

\author{
Kusuma Dewi, Tuisda Pratisia, Alfyananda Kurnia Putra* \\ Universitas Negeri Malang, Jl. Semarang No. 5 Malang, Jawa Timur, Indonesia \\ *Penulis korespondensi, Surel: alfyananda.fis@um.ac.id
}

Paper received: 01-05-2021; revised: 15-05-2021; accepted: 30-05-2021

\begin{abstract}
Abstrak
Merujuk pada fenomena penyebaran Covid-19 yang kian masif mempengaruhi proses pembelajaran, maka akademisi perlu mengadopsi atau memilih teknologi yang efektif. Melibatkan TIK secara efektif dan efisien dalam proses pembelajaran akan mendukung revolusi pendidikan menuju pencapaian tujuan pembelajaran abad 21. Penelitian ini bertujuan untuk mengajukan inovasi metode pembelajaran during untuk mencapai kognitif, psikomotorik, dan karakter siswa berbasis TIK di SMA Negeri 1 Batu. Adapun platform pembelajaran daring yang digunakan dalam penelitian ini yaitu google classroom dan google meet. Tidak hanya itu penggunaan media sosial dijadikan sebagai learning tools yaitu instagram. Dengan mengintegrasikan penggunaan google classroom, google meet, dan instagram ini maka dapat mempermudah guru maupun siswa dalam proses pembelajaran daring. Pengintegrasian tersebut memberikan pendidikan karakter disiplin, keaktifan, pencapaian kreativitas, melek informasi, berkolaborasi, dan tanggung jawab siswa. Sehingga inovasi metode ini dapat dijadikan alternatif dalam pembelajaran daring.
\end{abstract}

Kata kunci: pembelajaran daring; TIK; google classroom; google meet; instagram

\section{Pendahuluan}

Merujuk pada fenomena penyebaran Covid-19 yang kian masif, hal ini mempengaruhi berbagai bidang tak terkecuali dunia pendidikan. Proses pembelajaran mengalami revolusi, yang semula dilakukan tatap muka menjadi pembelajaran jarak jauh. Hal ini memberikan ketakutan tersendiri bagi siswa dalam proses pembelajaran. Ketakutan ini mulai dari ketakutan atas pengekangan aktivitas, ketakutan akan kegagalan belajar, dan ketakutan akan kehilangan hubungan sosial. Maka dari itu akademisi perlu mengadopsi atau memilih teknologi yang efektif dalam proses pembelajaran (Al-Maroof, R. S., et al., 2020).

Kondisi yang dipaparkan di atas, memberikan dorongan atas pencapaian tujuan pembelajaran abad 21. Subjek utama dalam pembelajaran abad 21 terdiri dari tiga hal (Tritiyatma, et al., 2017) yaitu: 1) Terampil belajar dan berinovasi; 2) Terampil menggunakan informasi, media, dan teknologi; dan 3) Terampil untuk hidup dan berkarir. Penyesuaian tujuan pembelajaran abad 21 dengan kondisi pandemi Covid-19 memiliki kesamaan secara dasar yaitu berfokus pada pembelajaran berbasis TIK. Melibatkan TIK secara efektif dan efisien dalam proses pembelajaran akan mendukung revolusi pendidikan (Sukmawati, 2020).

Pembelajaran berbasis TIK dapat diimplementasikan dengan berbagai pendekatan, salah satunya melalui pembelajaran selular atau mobile learning (m-learning). Mobile learning merupakan pembelajaran bergerak yang dapat dilakukan dimana dan kapanpun oleh siswa tanpa adanya batasan waktu maupun tempat dan menggunakan teknologi mobile (Claire, 2003). M-learning dapat mengubah mobile phone memiliki fungsi tambahan muatan pelajaran 
yang semula hanya digunakan untuk telepon, sms, dan internet menjadi perangkat untuk alat belajar yang lengkap (Yuniati, 2011). Pencapaian kognitif, psikomotorik, dan karakter siswa dalam penelitian ini dapat diperoleh dengan pengintegrasian metode selama proses pembelajaran. Adapun platform pembelajaran daring yang dapat digunakan yaitu google classroom dan google meet. Tidak hanya itu penggunaan media sosial umumnya juga dapat dijadikan sebagai learning tools, salah satunya yaitu instagram.

Google classroom yaitu aplikasi yang menggunakan jaringan internet dengan menggunakan computer dan/atau handphone (Hakim, 2016). Google classroom dapat mengaktifkan siswa pada proses pembelajaran disebabkan media ini dapat menampilkan teks, gambar, dan video pada saat proses pembelajaran berlangsung. Selain itu, aplikasi ini dapat 1) menyederhanakan kegiatan membuat, mendistribusikan, dan menilai tugas siswa tanpa harus bertatap muka langsung (Mahayoni, 2020; Okmawati, 2020); 2) melakukan percakapan tentang tugas dan guru dapat mengetahui kemajuan siswa (Beal, 2020); 3) menjadi media interaksi antara guru dengan siswanya atau siswa dengan siswa lainnya (Liu \& Chuang, 2016); dan 4) menampung dan mengatur waktu pengumpulan tugas oleh guru yang akan menumbuhkan rasa kedisiplinan dan tanggung jawab bagi siswa dalam mengerjakan tugas.

Google Meet adalah layanan panggilan video utama Google yang diluncurkan pertama kali pada tahun 2017. Ketersediaan Google Meet dapat memberikan solusi potensial dalam proses pembelajaran. Google Meet memiliki pengaruh yang sangat tinggi terhadap minat belajar siswa karena mudah digunakan, waktu yang fleksibel, dan dapat dilaksanakan dimana pun siswa berada (Septantiningtyas, 2020). Tautan Google Meet yang disediakan dalam setiap waktu kelas dapat digunakan beberapa kali yang memungkinkan siswa untuk terhubung dengan guru kapan saja (Al-Maroof, R.S., et al., 2020). Manfaat menggunakan Google Meet dibanding layanan lain adalah kesederhanaannya hanya dengan memiliki akun Google, selanjutnya langsung dapat memulai panggilan video.

Selanjutnya Instagram adalah salah satu aplikasi media sosial populer di kalangan pelajar untuk berbagi foto dan video. Instagram merupakan aplikasi sosial media yang sangat tepat digunakan sebagai media pembelajaran. Guru dapat secara aktif terhubung dengan siswanya (Zhang, 2013). Media ini juga memungkinkan adanya kolaboratif antara guru dan siswa dalam suatu tugas proyek pembelajaran (Bexbeti, 2014). Siswa dapat terlatih untuk mengkomunikasikan hasil karyanya kepada masyarakat luas dengan cara membagikannya pada akun masing-masing. Rasa tanggung jawab siswa juga akan terbangun karena terdapat dorongan untuk menyusun hasil karya yang baik. Pada media sosial ini karya siswa akan dinilai oleh banyak orang.

Penelitian ini bertujuan untuk mengajukan inovasi metode pembelajaran during untuk mencapai kognitif, psikomotorik, dan karakter siswa berbasis TIK. Media yang dimaksud yaitu google classroom, google meet, dan instagram. Dengan penerapan tersebut, diharapkan mobile learning mampu menjadi alternatif dalam pembelajaran during pada pandemi ini.

\section{Metode}

Jenis penelitian ini menggunakan metode kualitatif deskriptif. Metode yang digunakan tersebut untuk menemukan metode yang tepat sehingga dapat diimplementasikan pada proses pembelajaran secara luas (Arifin, 2013; Sugiyono, 2011). Metode pembelajaran ini memanfaatkan media google classroom, google meet, dan instagram yang dapat dijadikan alternatif pembelajaran oleh guru dalam proses pembelajaran during. Subjek penelitian ini 
yaitu siswa peminatan Ilmu Pengetahuan Sosial (IPS) kelas X di SMA Negeri 1 Batu. Penelitian ini melibatkan 35 siswa yaitu X IPS 4. Materi yang digunakan yaitu Dinamika Planet Bumi sebagai Ruang Kehidupan.

Teknik pengumpulan data dalam penelitian ini yaitu teknik dokumentasi dan observasi. Teknik analisis yang digunakan yaitu analisis induktif. Setelah data terkumpul, oleh peneliti akan dianalisis dan diinterpretasikan sehingga akan mudah dalam menarik kesimpulan akhir. Analisis data secara induktif yaitu segala hal yang bersifat khusus akan dicari dan ditarik kesimpulannya untuk dapat menjelaskan segala hal yang bersifat umum (Naserly, 2020). Segala hal yang ditemukan oleh peneliti akan dianalisis dan diobservasi melalui data dan berbagai studi kepustakaan. Hal ini untuk mencapai keberhasilan dalam penggunaan metode deskriptif melalui observasi sehingga terfokus pada tujuan penelitian.

Pada penelitian ini menggunakan beberapa tahap yakni tahap studi pendahuluan dengan mencari sumber yang menjelaskan penggunaan google classroom, google meet, dan instagram. Tahap kegiatan penelitian melibatkan siswa untuk menggunakan metode pembelajaran during. Selanjutnya pada tahap evaluasi yaitu dilakukan setelah pembelajaran menggunakan google classroom, google meet, dan instagram. Peneliti berharap dapat memberikan data tentang manfaat metode pembelajaran alternatif yang diterapkan selama proses pembelajaran Geografi secara daring.

\section{Hasil dan Pembahasan}

Penggunaan mobile learning dalam kegiatan belajar mengajar memiliki dampak yang positif bagi siswa yakni siswa dapat memanfaatkan waktu belajarnya dengan lebih fleksibel. Dengan demikian, terdapat peluang yang tinggi untuk meningkatkan hasil belajar siswa (Efendi \& Marpaung, 2018). Dalam penelitian ini platform yang digunakan untuk menunjang pembelajaran berbasis mobile learning adalah Google Meet, Google Classroom, dan aplikasi Instagram. Ketiga platform tersebut mudah untuk diaplikasi oleh guru dan siswa. Siswa sebagai generasi $\mathrm{Z}$ yang berada di era pembelajaran abad 21 sudah seharusnya untuk diberikan pengalaman belajar yang lebih menarik, menyenangkan, dan fleksibel dengan memanfaatkan teknologi yang sedang berkembang.

\subsection{Implementasi Google Meet}

Google meet merupakan suatu aplikasi video conference dari google yang memungkinkan penggunanya untuk melakukan panggilan video dengan 25 pengguna lainnya yang memiliki akun google atau lebih dalam satu pertemuan (Febriyanti, 2020; Rustaman, 2020). Google meet memiliki kelebihan seperti mudah diakses oleh guru dan siswa, tidak berbayar, selain itu google meet memiliki Interface atau antar muka yang sangat bermanfaat dengan ukuran yang tidak berat dan cepat, mengutamakan pengelolaan yang efisien, serta mudah digunakan (user friendly) sehingga dapat diaplikasikan oleh semua penggunanya dengan mudah (Sawitri, 2020). Jadi google meet merupakan platform dari google yang dapat digunakan untuk melakukan panggilan video yang mempermudah guru dan siswa dalam kegiatan belajar dan mengajar.

Penggunaan google meet pada pembelajaran daring ditujukan agar guru dan siswa tetap bisa berinteraksi antar muka secara on time walaupun berada di tempat yang berbeda. Sebab meskipun bahan ajar seperti modul, LKPD (Lembar Kegiatan Siswa), media pembelajaran (powerpoint) sudah dibagikan kepada siswa, guru tetap harus menjelaskan bagaimana proses 
pengerjaan, serta bagaimana teknik atau langkah siswa dalam belajar, siswa masih perlu dimonitoring terlebih dahulu. Untuk mencapainya maka google meet dapat dijadikan sebagai alternatif ketika pembelajaran daring (dalam jaringan). Tampilan pembelajaran menggunakan google meet disajikan pada Gambar 1.

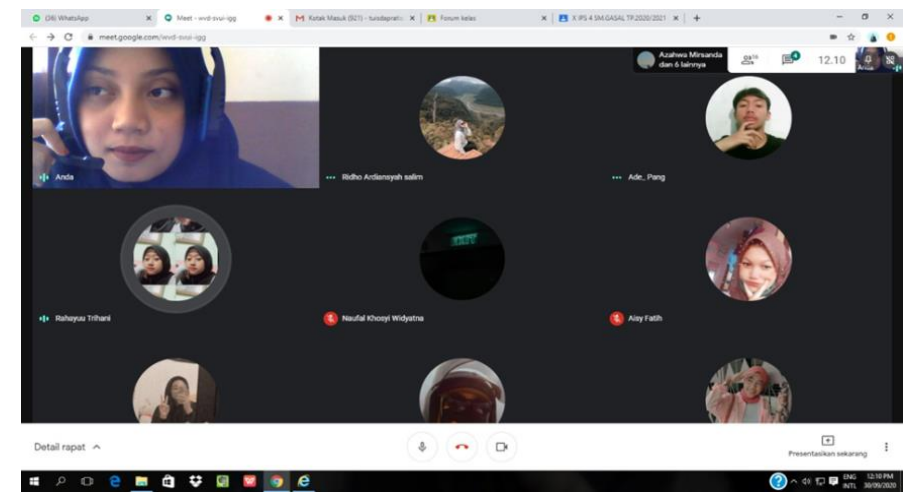

Gambar 1. Guru menjelaskan penugasan pada siswa melalui Google meet. Sumber: Dokumentasi pribadi

Kegiatan pembelajaran daring menggunakan platform google meet di SMA Negeri 1 Batu, dilakukan dengan guru sebagai host menyediakan room bagi siswa untuk bertemu di google meet secara daring. Selanjutnya guru melakukan presensi dengan meminta siswa untuk on camera. Kemudian guru memberikan gambaran terkait materi, teknis pembelajaran, penugasan, dan menyampaikan sedikit materi yang akan diberikan pada siswa. Melalui google meet guru bisa menyampaikan materi pembelajaran dengan didukung media pembelajaran seperti power point secara langsung dan saat itu juga meskipun secara jarak jauh. Sehingga siswa tetap bisa mendengarkan dan menyimak penjelasan sekaligus menyaksikan powerpoint seperti proses pembelajaran luring (luar jaringan). Selain itu siswa juga dapat berdiskusi dengan guru maupun siswa lainnya untuk membahas materi pada saat itu juga.

Dengan memanfaatkan google meet kegiatan belajar dan mengajar bisa tetap berlangsung meskipun dilaksanakan dalam jarak jauh, selain itu dengan pemanfaatan google meet siswa dapat memperoleh pengalaman baru dalam belajar. Hal ini sesuai dengan pernyataan Juniarti (2020) dimana google meet dapat dijadikan sebagai sarana pembelajaran yang menunjang proses pembelajaran siswa sekaligus melatih siswa untuk dapat memanfaatkan teknologi dalam kehidupannya. Tak hanya itu pemanfaatan google meet juga dapat melatih keterampilan menyimak siswa. Namun, seperti platform-platform online lainnya, google meet juga memiliki kendala dalam pemanfaatannya salah satunya adalah terbatasnya paket internet atau paket data siswa sehingga terdapat beberapa siswa yang tidak bisa mengikuti google meet. Untuk mengatasi ketertinggalan materi oleh siswa yang tidak dapat mengikuti google meet, guru mengirimkan materi yang telah diajarkan melalui grup whatsApp maupun google classroom sehingga siswa masih bisa mengakses materi dan mendiskusikannya dengan guru ketika mengalami kesulitan.

\subsection{Implementasi Google Classroom}

Google Classroom (GC) merupakan platform berbasisi internet yang disediakan oleh google sebagai sistem manajemen pembelajaran yang bertujuan untuk memudahkan penyusunan, penyebaran, dan penilaian tugas secara online (Wicaksono, 2020; Qomariah, 2019). Dengan menggunakan google classroom guru dapat memberikan pengumuman, tugas, 
materi pembelajaran serta mengetahui siapa saja yang telah dan yang belum mengumpulkan tugas, sedangkan siswa dapat mengumpulkan tugas serta mengakses materi yang telah diberikan guru kapanpun dan dimanapun. Hal tersebut sesuai dengan pernyataan Ali (2020) dimana google classroom dapat membangun suasana belajar yang lebih produktif dan bermakna bagi siswa dengan menyederhanakan tugas, meningkatkan kerjasama, serta membina komunikasi, tidak hanya itu dengan google classroom guru dapat membuat kelas, memberikan tugas, memberikan penilaian pada satu tempat. Gambar 2 adalah contoh penggunaan google classroom dalam pembelajaran daring.

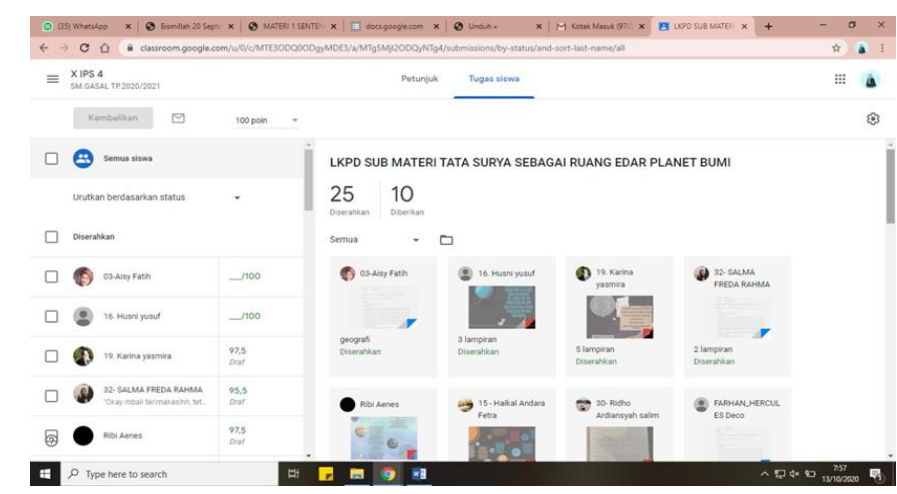

Gambar 2. Tampilan Google Classroom pada menu penugasan Sumber: Dokumen pribadi

Google Classroom terhubung dengan semua layanan Google for Education lainnya, salah satunya adalah Google Calendar. Pemanfaatan Google Calendar sebagai pengingat tenggat waktu pengumpulan tugas oleh siswa di Google Classroom dapat meningkatkan kedisiplinan siswa. Hal tersebut dikarenakan siswa akan mengetahui kapan deadline dari tugas mereka, sehingga mereka dengan mudah dapat mengumpulkan tugas secara tepat waktu. Hal tersebut sesuai dengan penelitian Prada (2017) dimana ia menyatakan bahwa dengan memanfaatkan Google Calendar maka tidak terdapat alasan lagi bagi siswa untuk lupa atau bahkan terlambat mengumpulkan tugas. Selain terkait pengumpulan tugas, guru juga dapat menyimpan file perangkat pembelajaran seperti modul, powerpoint, dan file lainnya yang akan digunakan dalam proses pembelajaran.

Penggunaan Google Classroom dalam kegiatan pembelajaran online (daring) selama pandemi Covid-19 di SMA Negeri 1 Batu dilakukan dengan cara guru membuat room google classroom untuk siswa dan guru. Selanjutnya siswa bergabung di room yang sudah disediakan dengan memasukkan kode kelas terlebih dahulu. Kemudian guru dapat memanfaatkan google classroom untuk mendistribusikan materi atau tugas dengan cara memposting file- file materi atau tugas di google classroom, sehingga dapat diakses secara langsung oleh seluruh siswa yang sudah bergabung di dalamnya. Untuk penilaian guru dapat langsung menilai hasil kerja siswa, selain itu dengan menggunakan google classroom guru dapat mengetahui jumlah siswa yang sudah dan siswa yang belum mengumpulkan tugas. Hal tersebut sesuai dengan pernyataan Aryani (2020) dimana, dengan menggunakan google classroom guru akan lebih mudah dalam melakukan evaluasi terhadap proses belajar siswa. Dengan adanya layanan google classroom yang cukup lengkap maka pembelajaran secara daring dapat dilaksanakan dengan efektif dan efisien. Hal tersebut sejalan dengan pendapat Ashadi (2020) yang menyatakan bahwa google classroom dapat menjadi suatu media distribusi tugas, pengumpulan tugas, bahkan penilaian 
tugas-tugas oleh guru, sehingga dapat membantu memudahkan guru dan siswa dalam proses belajar secara mendalam.

Pemanfaatan google classroom dalam kegiatan belajar dan mengajar di SMA Negeri 1 Batu tidak menutup kemungkinan terjadinya suatu kendala. Sebab dalam praktiknya, masih terdapat siswa yang tidak dapat hadir untuk mengikuti pembelajaran. Ketidakhadiran siswa sebagian besar diakibatkan oleh tidak adanya jaringan internet yang memadai untuk mengakses google classroom. Wicaksono (2020), dalam penelitiannya juga menyatakan bahwa kenyataan di lapangan kendala dalam pemanfaatan google classroom adalah jaringan internet yang belum bisa diakses siswa secara keseluruhan.

\subsection{Implementasi Instagram}

Pemanfaatan media sosial (medsos) sebagai salah satu media pembelajaran telah diterapkan dalam beberapa penelitian. Media sosial dapat dimanfaatkan menjadi media $e$ learning untuk mencapai kemampuan berkolaborasi dan berbagi bagi siswa (Nurkamid, dkk., 2010). Instagram merupakan suatu aplikasi yang digunakan untuk mengambil foto, mengedit foto dengan fitur filter, dan membagikan foto ke berbagai pengguna jejaring sosial yang ada, termasuk ke pengguna Instagram itu sendiri (Utomo, 2012). Gambar 3 adalah penggunaan instagram dalam kegiatan pembelajaran di SMA Negeri 1 Batu.

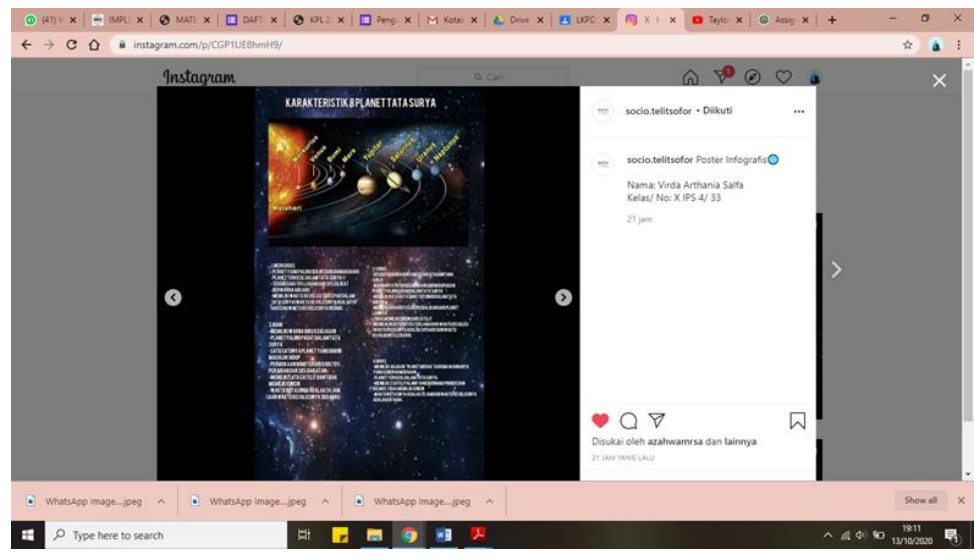

Gambar 3. Tampilan tugas infografis yang diposting siswa pada Instagram kelas. Sumber: Dokumentasi pribadi

Instagram digunakan sebagai media pembelajaran oleh guru. Guru memberikan penugasan kepada siswa dengan memanfaatkan fitur Instagram. Tugas yang diberikan adalah 1) membuat proyek infografis materi bumi dan kehidupannya; 2) memposting infografis pada akun Instagram kelas; dan 3) siswa dapat memberikan pendapat pada kolom komentar setiap infografis yang diposting. Tujuan dari penugasan tersebut adalah guru dapat menilai tingkat kreativitas siswa dalam membuat infografis. Penugasan ini akan memberikan dorongan kepada siswa untuk dapat belajar membagikan hasil kerjanya dengan konten pembelajaran. Instagram sebagai sarana penyampaian informasi (Ardiana \& Aristana, 2021). Selain itu, akan menuntut siswa memiliki rasa tanggung jawab atas apa yang mereka tulis dari hasil proyek tersebut, hal ini dikarenakan infografis akan dilihat oleh pengguna lainnya secara global. Dengan demikian, penggunaan media sosial akan memberikan kesan belajar menyenangkan bagi siswa (Afrizal, 2020). 


\subsection{Evaluasi}

Evaluasi (penilaian) adalah salah satu cara untuk meningkatkan kualitas pembelajaran. Penilaian menggunakan metode pembelajaran google meet, google classroom, dan Instagram dilakukan beberapa kali tahapan. Adapun yang dievaluasi adalah aspek kognitif (pengetahuan), keterampilan, dan karakter siswa dengan melihat hasil dari penerapan ketiga metode yang disebutkan sebelumnya.

Penilaian pengetahuan didasarkan pada hasil kerja siswa yakni tanya jawab secara langsung melalui google meet dalam proses pembelajaran berlangsung serta jawaban siswa pada LKPD. Tanya jawab secara langsung selain sebagai penilaian juga dapat digunakan sebagai bentuk interaksi antara guru dan siswa, dengan begitu guru dapat mengetahui materi apa saja yang belum dikuasai dan dipahami oleh siswa. Penggunaan google meet ini akan mendorong peningkatan keaktifan siswa dalam pembelajaran daring.

Penilaian keterampilan siswa diperoleh dari hasil kerja siswa dalam membuat infografis, dimana siswa dilatih untuk membuat karya yang asli sesuai kreativitas individu. Dengan adanya infografis tersebut siswa juga dilatih untuk mengintegrasikan antara gambar dengan penjelasan materi yang sesuai. Selanjutnya mendesainnya ke dalam bentuk infografis yang sederhana untuk kemudian diposting pada instagram kelas. Dengan memposting tugas di instagram maka siswa akan memperoleh pengalaman menyenangkan dalam menggunakan media sosial untuk berbagi informasi, berkomunikasi, dan memperoleh banyak teman (Sari, 2017). Selain itu siswa juga dapat melatih keterampilan komunikasi mereka melalui penyusunan kalimat yang dituliskan dalam infografis. Penggunaan Instagram ini akan mendukung peningkatan kemampuan berpikir kreatif siswa (Utami, 2015).

Penilaian karakter (sikap) khususnya tepat waktu atau kedisiplinan dalam penelitian ini diperoleh dari ketepatan waktu siswa dalam menyerahkan tugas pada google classroom. Dengan menggunakan google classroom maka siswa akan mengetahui deadline tugas mereka. Selain itu siswa akan terhindar dari keterlambatan pengumpulan tugas ketika guru mengaktifkan pemberitahuan deadline tugas pada siswa dengan menggunakan google calendar. Hal tersebut memiliki kesamaan dengan penelitian Pradana (2017) dimana proses pembelajaran yang menggunakan Google Classroom akan lebih menarik dan lebih praktis dalam hal manajemen waktu, sebab tidak ada alasan lagi bagi siswa untuk lupa mengumpulkan tugas yang sudah diberikan oleh guru.

Dengan penggunaan Google Classroom, Google Meet, dan Instagram ini maka dapat mempermudah para guru dan siswa dalam kegiatan belajar dan mengajar. Selain itu, kegiatan belajar mengajar yang mengintegrasikan ketiga media tersebut dapat memberikan pendidikan karakter disiplin dalam penyelesaian dan mengumpulkan tugas, sebab guru dapat mengatur deadline pengumpulan tugas. Dengan metode tersebut proses pembelajaran dapat dilakukan dimana saja dan dapat diakses kapanpun oleh guru dan siswa.

\section{Simpulan}

Dengan penggunaan google meet, google classroom, dan instagram ini maka dapat mempermudah para guru maupun siswa dalam kegiatan proses pembelajaran daring. Mengintegrasikan ketiga media tersebut dapat memberikan pendidikan karakter disiplin, keaktifan, pencapaian kreativitas, melek informasi, berkolaborasi, dan tanggung jawab. Karakter disiplin siswa dapat dicapai karena aplikasi google classroom menyediakan setting 
waktu pengerjaan dan pengumpulan tugas. Guru dapat mengatur waktu pengumpulan tugas secara mudah. Selanjutnya pada pencapaian keaktifan ini dapat diukur dengan minat siswa dalam pembelajaran google meet. Sedangkan Instagram juga memberikan kontribusi pencapaian kreativitas siswa dalam menggunakan media sosial sebagai media pembelajaran. Adapun saran untuk penelitian lanjutan yaitu perlu dilakukan penelitian lanjutan melalui pemberian kuesioner penilaian kepada siswa tentang efektivitas aplikasi google meet, google classroom, dan instagram dalam proses pembelajaran online.

\section{Daftar Rujukan}

Afrizal, D.Y. (2020). Media Sosial Instagram Sebagai Sarana Pembelajaran Menulis Teks Deskripsi. Prosiding SAMASTA, Seminar Nasional Bahasa dan Sastra Indonesia, 62-66.

Al-Maroof, R.S., et al. (2020): Fear from COVID-19 and technology adoption: the impact of Google Meet during Coronavirus pandemic. Interactive Learning Environments, 1-16.

Ardiana, D.P.Y \& Aristana, M.D.W. (2021). Pemanfaatan Media Sosial Instagram Sebagai Media Pembelajaran Alternatif Dalam Mata Kuliah Pemrograman. Prosiding Seminar Nasional Desain dan Arsitektur (SENADA), 4: 39-45.

Aryani, D., Malabay, M., Ariessanti, H. D., \& Putra, S. D. (2020). Pelatihan Pemanfaatan Google Classroom untuk Mendukung Kegiatan Pembelajaran Daring saat Pandemi COVID 19 di SMPIT Insan Rabbani. Jurnal Abdidas, 1(5), 373-378.

Arifin, Z. (2011). Evaluasi Pembelajaran - Prinsip Teknik Prosedur. Bandung: PT Remaja Rosdakarya.

Ashadi, N. R., \& Suhaeb, S. (2020). Hubungan Pemanfaatan Google Classroom dan Kemandirian terhadap Hasil Belajar Mahasiswa PTIK pada Masa Pandemi. Jurnal Media Elektrik, 17(2), 46-51.

Beal, V. (2020). Google Classroom. Editor of webopedia.

Bexheti, L. A., Ismaili, B. E., \& Cico, B. H. (2014, March). An analysis of social media usage in teaching and learning: The case of SEEU. In Proceedings of the 2014 International Conference on Circuits, Systems, Signal Processing, Communications and Computers (pp. 90-94).

Blundo, D. A. (2011). E-learning Methodologies. A Guide for Designing and Developing e-learning Courses. Rome: Food and Agriculture Organization of the United Nations.

Efendi, S \& Marpaung, R. F. (2018). Implementasi Mobile Learning Dengan Model Advance Organizer Dalam Meningkatkan Kemampuan Kognitif Kimia Mahasiswa. PeTeKa Jurnal Penelitian Tindakan Kelas dan Pengembangan Pembelajaran, 1(3): 171-178.

Febriyanti, R. H., \& Sundari, H. (2020). Penerapan Penggunaan Platform Dalam Pengajaran Bahasa Inggris Berbasis Daring. RANGKIANG: Jurnal Pengabdian Pada Masyarakat, 2(1), 17-27.

Hakim, A. B. (2016). Efektivitas Penggunaan E-Learning Moodle, Google Classroom Dan Edmodo. ISTATEMENT, 2: 1-6.

Juniartini, N. M. E., \& Rasna, I. W. (2020). Pemanfaatan Aplikasi Google Meet Dalam Keterampilan Menyimak Dan Berbicara Untuk Pembelajaran Bahasa Pada Masa Pandemi Covid-19. Jurnal Pendidikan dan Pembelajaran Bahasa Indonesia, 9(2), 133-141.

Liu, H. C., \& Chuang, H. H. (2016). Integrating Google Classroom to Teach Writing in Taiwan. Minnesota eLearning Summit.

Mahayoni, N. M. S. (2020). Penggunaan Aplikasi Zoom Meeting Pada Pembelajaran Agama Hindu Di Masa Pandemi. Jurnal Widya Sastra Pendidikan Agama Hindu, 3(1), 47-53.

Naserly, M. K. (2020). Implementasi Zoom, Google Classroom, Dan Whatsapp Group Dalam Mendukung Pembelajaran Daring (Online) Pada Mata Kuliah Bahasa Inggris Lanjut. EDUTECH CONSULTANT BANDUNG Jurnal AKSARA PUBLIC, 4(2): 155-165.

Nurkamid, M., Dahlan, M., Susanto, A., \& Khotimah, T. (2010). Pemanfaatan aplikasi jejaring sosial facebook untuk media pembelajaran. Sains dan Teknologi, 3(2), 1-16.

O'Malley, C., Vavoula, G., Glew, J. P., Taylor, J., Sharples, M., Lefrere, P., ... \& Waycott, J. (2005). Guidelines for learning/teaching/tutoring in a mobile environment. 
Jurnal Integrasi dan Harmoni Inovatif Ilmu-Ilmu Sosial, 1(5), 2021, 533-541

Okmawati, M. (2020). The Use of Google Classroom During Pandemic. Journal of English Language Teaching, 9(2): 439-443.

Pradana, D. B. P. (2017). Pengaruh Penerapan Tools Google Classroom Pada Model Pembelajaran Project Based Learning Terhadap Hasil Belajar Siswa. IT-Edu: Jurnal Information Technology and Education, 2(1).

Qomariah, S., \& Nursobah, S. L. (2019). Implementasi Pemanfaatan Google Classroom untuk pembelajaran di Era Revolusi 4.0. SINDIMAS, 1(1), 227-231.

Rustaman, A. H. (2020). Efektivitas penggunaan aplikasi daring, video conference dan sosial media pada mata kuliah komputer grafis 1 di masa pandemi covid-19. JISIP (Jurnal Ilmu Sosial dan Pendidikan), 4(3).

Sari, M. P., \& Lubis, E. E. (2017). Fenomena penggunaan media sosial instagram sebagai komunikasi pembelajaran agama Islam oleh mahasiswa FISIP Universitas Riau (Doctoral dissertation, Riau University).

Septantiningtyas, N., et al. (2020). Implementation of Google Meet Application in the Learning of Basic Science in the Covid-19 Pandemic Period of Student Learning Interests. 2nd Bukittinggi International Conference on Education (BICED), Journal of Physics: Conference Series, 1-6.

Sawitri, D. (2020). Penggunaan Google Meet Untuk Work from Home Di Era Pandemi Coronavirus Disease 2019 (Covid-19). Prioritas: Jurnal Pengabdian Kepada Masyarakat, 2(01), 13-21.

Sugiyono, S. (2011). Metode Penelitian Kuantitatif, Kualitatif, dan R\&D. Bandung: Alfabeta.

Sukmawati, S. (2020). Implementasi Pemanfaatan Google Classroom Dalam Proses Pembelajaran Online di Era Industri 4.0. Jurnal Kreatif Online, 8(1): 39-46.

Tritiyatma, T. (2017). Keterampilan Abad 21 Dan Steam (Science, Technology, Engineering, Art and Mathematics) Project Dalam Pembelajaran Kimia. Republik Indonesia: Kementerian Hukum dan Hak Asasi Manusia, Direktorat Jenderal Kekayaan Intelektual u.b. Direktur Hak Cipta dan Desain Industri.

Utami, R. P., Probosari, R. M., \& Fatmawati, U. M. I. (2015). Pengaruh Model Pembelajaran Project Based Learning Berbantu Instagram Terhadap Kemampuan Berpikir Kreatif Siswa Kelas X SMA Negeri 8 Surakarta. Bio-Pedagogi, 4(1), 47-52.

Wicaksono, M. D. (2020). Pemanfaatan Google Classroom dalam Strategi Pembelajaran Kooperatif pada Mata Pelajaran IPS Kelas VIII. Inspirasi (Jurnal Ilmu-IImu Sosial), 17(1).

Yuniati, L. (2011). Pengembangan Media Pembelajaran Mobile Learning Efek Doppler Sebagai Alat Bantu Dalam Pembelajaran Fisika Yang Menyenangkan. JP2F 2(2).

Zhang, L. 2013. Mobile phone technology engagement in EFL classroom. International Conference on Software and Computer Science (ICSECS): 171-173. 